\title{
LEMNA MINOR INFLUENCE IN THE TREATMENT OF ORGANIC POLLUTION OF THE INDUSTRIAL EFFLUENTS
}

\author{
Karina Alvarado \\ Universidad Tecnológica del Perú, Lima, (Perú). \\ E-mail: c10208@utp.edu.pe ORCID: https://orcid.org/0000-0001-7142-4212
}

Doris Esenarro

National University Federico Villarreal, Lima, (Perú). E-mail: desenarro@unfv.edu.pe ORCID: https://orcid.org/0000-0002-7186-9614

Ciro Rodriguez

National University Mayor de San Marcos, Lima, (Perú). E-mail: crodriguezro@unmsm.edu.pe ORCID: https://orcid.org/0000-0003-2112-1349

Wilson Vasquez

Universidad Tecnológica del Perú, Lima, (Perú). E-mail: c18347@utp.edu.pe ORCID: https://orcid.org/0000-0001-7064-028X

Recepción: 08/06/2020 Aceptación: 20/07/2020 Publicación: 14/09/2020

\section{Citación sugerida:}

Alvarado, K., Esenarro, D., Rodriguez, C., y Vasquez, W. (2020). Lemna minor influence in the treatment of organic pollution of the industrial effluents. 3C Tecnología. Glosas de innovación aplicadas a la pyme, 9(3), 77-97. https://doi. org/10.17993/3ctecno/2020.v9n3e35.77-97 


\section{ABSTRACT}

The purpose of the research was to determine the influence of industrial wastewater treatment using the Lemna Minor aquatic plant. Certain varieties of macrophyte plants can absorb or retain various contaminants. Thanks to this, it has been determined that the variety known as Lemna Minor presents this type of property. Three treatment trials were carried out varying the amounts of Lemna Minor (100, 200, and 300g). They are keeping constant the retention time of 10 days that were analyzed at 3, 6, and 10 days after the treatment and with a constant volume of the residual effluent. The results indicate that in terms of the parameters that determine organic contamination, BOD was reduced by (61\%); COD was reduced by $(68 \%)$ and the concentration of total suspended solids by (61\%).

\section{KEYWORDS}

Lemna minor, Organic pollution, Industrial effluents, Wastewater treatment, Macrophyte plants. 


\section{INTRODUCTION}

The effluents from industrial processes coming from dyestuffs present organic matter expressed as chemical oxygen demand (COD), biochemical oxygen demand (BOD), and total suspended solids (TSS). The bathing ratios (BR) in these types of processes comprise 1:7 to 1:12; this leads to the use of large quantities of water. These effluents must be treated before being introduced into the industrial drainage system, to comply with national regulations related to the use of public sewage systems and to avoid contamination of the receptors.

The main benefit of treatment systems with aquatic plants is their low cost of construction and maintenance, as well as their simplicity of operation using an available resource.The presence of a large amount of organic contamination depletes the oxygen in the water, resulting in a decrease in the appropriate conditions for life, producing fermentations that lead to bad odors. The sedimented solids, many of them are toxic because they carry heavy metals such as $\mathrm{Cu}, \mathrm{Mn}, \mathrm{Cd}$ and $\mathrm{Cr}$ (Hoyos et al., 2016).

In this research thesis: Influence of the use of Lemna minor in the treatment of organic contamination of industrial effluents in Cotexsur. The objective of the present work was to determine the influence of the treatment of industrial wastewater from the company Cotexsur, using the aquatic plant Lemna Minor. The research was of an applied type and experimental design with a quantitative approach. The sample was taken considering the convenience and criteria previously evaluated by the types of analysis performed and the treatment proposed (Sun et al., 2020; Walsh et al., 2020).

The theoretical bases that support the research, thus, the advantages of using the Lemna Minor, previous definitions of textile dyes, and parameters for measuring organic contamination. The research was also carried out with Lemna Minor, which has a percentage of removal expressed as COD 72.57 \%, BOD5 $73.36 \%$, total solids $75.21 \%$ and in the first six days of treatment with different masses of $100 \mathrm{~g}, 200 \mathrm{~g}$ of Lemna Minor there is a high percentage of decrease in the concentrations of the mentioned parameters (Hoyos et al., 2016; Li et al., 2020). 


\section{METHOD AND INSTRUMENTS}

The measurements obtained are analyzed (often using statistical methods). The sample was considered according to convenience. The criteria previously evaluated, the types of analysis performed, and the treatment proposed, therefore the sample was non-probabilistic.

The total volume of the sample was 70 liters from the industrial textile effluents. These 70 liters will be divided into 3 types of treatment: 100g, 200g, and 300g of Lemna Minor and each of the treatments with 7 experimental runs (Coronel, 2016).

For the collection of data, as Rodriguez et al. (2020), which made it possible to have better control over the data that allowed the characterization of the effluents from Cotexsur. The following equipment was used to obtain the concentrations of the parameters:

- $\quad$ HI 2210 potentiometer.

- $\quad$ COD digester DRB 200.

- Colorimeter DR 900.

- Equipment for determining BOD.

- Analytical balance NBL 124 E.

- Digital sterilization and drying oven DHG 9023 A.

- Button lid dryer, $150 \mathrm{~mm}$.

The equipment and materials for the analyses were provided by the laboratory of the Universidad Autónoma del Perú, which allowed to determine: PH, Biochemical Oxygen Demand, Chemical Oxygen Demand, and Total Suspended Solids (Jojoa, Rodríguez, \& Cardona, 2015). 


\subsection{ST COLLECTION AND IDENTIFICATION OF LEMNA MINOR}

From the lagoons adjacent to the villa marshes in the Chorrillos district, samples of Lemna Minor were collected to be used in the experimental runs, considering the following conditions:

- Have good pigmentation

- That they do not present an anomaly in any of their parts.

The laboratory where the analyses were carried out has adequate ventilation and sunlight. The temperature and humidity in the experimental runs were:

- Maximum temperature: 210G

- Minimum temperature: $180 \mathrm{C}$

- Humidity: $89 \%$.

\subsection{ND COLLECTION AND ANALYSIS OF SAMPLES OF THE INDUSTRIAL EFFLUENTS OF COTEXSUR}

Wastewater analysis was performed according to standardized methods (Standard Methods for the examination wáter and wastewater, APHA) and instruments, equipment, reagents, which are recommended in the methods. Table 1 details the method or technique applied for each analysis parameter.

Table 1. Health quality monitoring protocol, according to DIGESA (Dirección General de Salud Ambiental).

\begin{tabular}{|c|c|c|}
\hline $\begin{array}{c}\text { Parameters /Dimension of the } \\
\text { dependent variable }\end{array}$ & Method / Technique & Bottle material \\
\hline Biochemical Oxygen Demand & Dilution & Plastic or glass \\
\hline Biochemical Oxygen Demand & Colorimetric & Plastic or glass \\
\hline Total suspended solids & Gravimetric & Plastic or glass \\
\hline PH & Electrometric & Field Determination \\
\hline
\end{tabular}

Source: (Dirección General de Salud Ambiental e Inocuidad Alimentaria (DIGESA), s.f.). 


\section{RESULTS}

\subsection{DESCRIPTIVE}

The results obtained in the development of the research are presented below:

Table 2. Distribution of average BOD concentrations vs. treatment time for $100 \mathrm{~g}$ mass of Lemna Minor.

\begin{tabular}{|c|c|c|}
\hline $\begin{array}{c}\text { Mass Lemna } \\
\text { Minor (g) }\end{array}$ & Time (Days) & $\begin{array}{c}\text { Media DBO } \\
\text { (ppm) }\end{array}$ \\
\hline 100 & 0 & 823 \\
\hline 100 & 3 & 518 \\
\hline 100 & 6 & 389 \\
\hline 100 & 10 & 319 \\
\hline
\end{tabular}

Source: authors' own elaboration.

Table 2 and Figure 1 show the decrease in the average concentration of BOD as a function of time, for a mass in contact of $100 \mathrm{~g}$ of Lemna Minor, the average BOD concentration in the initial time was 823 ppm; when in contact for 3 days the average concentration of BOD decreases to $518 \mathrm{ppm}$; for 6 days of treatment the BOD concentration was 369 ppm, and for 10 days the BOD concentration was reduced to a concentration of 319 ppm. (Esenarro et al., 2020).

Table 3. Distribution of average BOD concentration vs. treatment time for $200 \mathrm{~g}$ Mass of Lemna Minor.

\begin{tabular}{|c|c|c|}
\hline $\begin{array}{c}\text { Mass Lemna } \\
\text { Minor (g) }\end{array}$ & Time (days) & $\begin{array}{c}\text { Media DBO } \\
\text { (ppm) }\end{array}$ \\
\hline 200 & 0 & 823 \\
\hline 200 & 3 & 468 \\
\hline 200 & 6 & 346 \\
\hline 200 & 10 & 389 \\
\hline
\end{tabular}

Source: authors' own elaboration. 
In Table 3, we can see the decrease in the average concentration of the biochemical oxygen demand as a function of time. For a mass in contact of $200 \mathrm{~g}$ of Lemna Minor, the average concentration for the initial contact time was 823 ppm; when in contact for 3 days, the average concentration of the biochemical oxygen demand decreased to 468 ppm; for 6 days of treatment, the BOD concentration decrease to $346 \mathrm{ppm}$ for 10 days, the BOD concentration was reduced to $389 \mathrm{ppm}$.

Table 4. Distribution of average BOD concentration vs. treatment time for $300 \mathrm{~g}$ mass of Lemna Minor.

\begin{tabular}{|c|c|c|}
\hline $\begin{array}{c}\text { Mass Lemna } \\
\text { Minor (g) }\end{array}$ & Time (days) & $\begin{array}{c}\text { Media DBO } \\
\text { (ppm) }\end{array}$ \\
\hline 300 & 0 & 823 \\
\hline 300 & 3 & 429 \\
\hline 300 & 6 & 331 \\
\hline 300 & 10 & 533 \\
\hline
\end{tabular}

Source: authors' own elaboration.

In Table 4, the decrease in time-averaged BOD concentrations for a contact mass of $300 \mathrm{~g}$ of Lemna Minor is shown. The average concentration for the initial treatment time was $823 \mathrm{ppm}$. This, when in contact for 3 days, the average concentration of BOD decreases to $429 \mathrm{ppm}$. For 6 days of contact, the BOD concentration was $331 \mathrm{ppm}$, and for 10 days, the BOD concentration was 533 ppm.

Table 5. Distribution of average BOD concentration vs. treatment time and mass of Lemna Minor.

\begin{tabular}{|c|c|c|c|c|}
\hline Mass $\mathbf{( g )}$ & Time (days) & $\begin{array}{c}\text { BOD average } \\
\mathbf{( p p m )}\end{array}$ & $\begin{array}{c}\text { Standard } \\
\text { deviation }\end{array}$ & $\mathbf{N}$ \\
\hline & 0 days & 833,57 & 26,018 & 7 \\
\hline \multirow{2}{*}{100} & 3 days & 517,71 & 34,028 & 7 \\
& 6 days & 389,43 & 29,205 & 7 \\
& 10 days & 318,57 & 20,354 & 28 \\
\hline
\end{tabular}




\begin{tabular}{|c|c|c|c|c|}
\hline Mass $\mathbf{( g )}$ & Time (days) & $\begin{array}{c}\text { BOD average } \\
\mathbf{( p p m )}\end{array}$ & $\begin{array}{c}\text { Standard } \\
\text { deviation }\end{array}$ & $\mathbf{N}$ \\
\hline & 0 days & 822,57 & 26,018 & 7 \\
\hline \multirow{2}{*}{200} & 3 days & 468,29 & 34,898 & 7 \\
& 6 days & 345,57 & 33,125 & 7 \\
\hline & 10 days & 388,57 & 30,237 & 28 \\
\hline & Total & 506,25 & 193,563 & 7 \\
\hline & 0 days & 822,57 & 26,018 & 7 \\
\hline & 3 days & 429,43 & 27,367 & 7 \\
\hline & 6 days & 331,43 & 15,736 & 28 \\
\hline & 10 days & 532,86 & 17,995 & 21 \\
\hline & Total & 529.07 & 188,367 & 21 \\
\hline & 0 days & 822,57 & 24,683 & 21 \\
\hline & 3 days & 471,81 & 48,041 & 21 \\
\hline
\end{tabular}

Source: authors' own elaboration.

Table 5 shows the averages of BOD concentration versus treatment time at different masses of Lemna Minor. The results obtained according to ANOVA show that the greatest decrease in BOD concentration was for a mass of $100 \mathrm{~g}$ of Lemna Minor and 10 days of treatment with a decrease in the concentration of biochemical oxygen demand from $823 \mathrm{ppm}$ to $319 \mathrm{ppm}$.

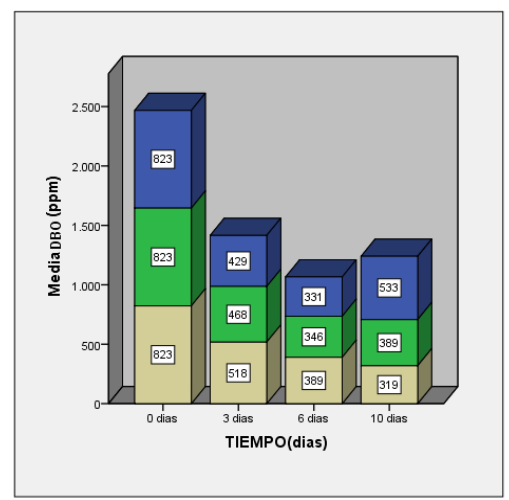

ASA(gramos)

Q300 gramos
$\square 00$ gramos
$\square 100$ gramos

然

Figure 1. Average BOD concentration levels vs. treatment time and mass of Lemna Minor. Source: authors' own elaboration. 
Figure 1 shows the decrease in average BOD concentration for a treatment time of 10 days and mass of 100 Lemna Minor $\mathrm{g}$ from 823 to $319 \mathrm{ppm}$. With a treatment of $200 \mathrm{~g}$ of Lemna Minor, the BOD concentration decreases in 6 days from 823 ppm to $346 \mathrm{ppm}$ and then increases in 10 days to $389 \mathrm{ppm}$, the same behavior is obtained for treatment with $300 \mathrm{~g}$ of Lemna Minor. The BOD concentration decreases in 6 days from 823 ppm to 331 ppm, concluding: a better treatment of organic contamination expressed as BOD is obtained with a mass of $100 \mathrm{~g}$ of Lemna Minor.

Table 6. Distribution of average COD concentrations vs. treatment time for a mass of $100 \mathrm{~g}$ of Lemna Minor.

\begin{tabular}{|c|c|c|}
\hline $\begin{array}{c}\text { Mass Lemna } \\
\text { Minor (g) }\end{array}$ & Time (days) & $\begin{array}{c}\text { DQO average } \\
\text { (ppm) }\end{array}$ \\
\hline 100 & 0 & 1747 \\
\hline 100 & 3 & 1062 \\
\hline 100 & 6 & 749 \\
\hline 100 & 10 & 554 \\
\hline
\end{tabular}

Source: authors' own elaboration.

In Table 6, we can see the decrease in the average concentration of chemical oxygen demand as a function of time for a treatment with a mass of Lemna Minor of $100 \mathrm{~g}$ of Lemna Minor, the average concentration in the initial time was 1747 ppm; when being in contact for a period of 3 days, the average concentration of chemical oxygen demand decreases to 1062 ppm; for 6 days of contact the COD concentration was 749 ppm, and in 10 days a COD concentration of 554 ppm is obtained, obtaining a considerable reduction.

Table 7. Distribution of average COD concentrations vs. treatment time for $200 \mathrm{~g}$ mass of Lemna Minor.

\begin{tabular}{|c|c|c|}
\hline $\begin{array}{c}\text { Mass Lemna } \\
\text { Minor } \mathbf{( g )}\end{array}$ & Time (days) & $\begin{array}{c}\text { DQO average } \\
\text { (ppm) }\end{array}$ \\
\hline 200 & 0 & 1747 \\
\hline 200 & 3 & 913 \\
\hline 200 & 6 & 603 \\
\hline 200 & 10 & 684 \\
\hline
\end{tabular}

Source: authors' own elaboration. 
Table 7 show the decrease in the time-averaged concentrations of the chemical oxygen demand for a treatment with a Lemna Minor mass of $200 \mathrm{~g}$ Lemna Minor. The average concentration in the initial time was 1747 ppm; when in contact with Lemna Minor for 3 days the average concentration of the chemical oxygen demand decreases to 913 ppm; for 6 days of contact with Lemna Minor the COD concentration was $603 \mathrm{ppm}$, and for 10 days an increase in the COD concentration to $684 \mathrm{ppm}$ is obtained.

Table 8. Distribution of average COD concentrations vs. treatment time for $300 \mathrm{~g}$ mass of Lemna Minor.

\begin{tabular}{|c|c|c|}
\hline $\begin{array}{c}\text { Mass Lemna Minor } \\
(\mathbf{g})\end{array}$ & Time (days) & $\begin{array}{c}\text { DQO average } \\
\text { (ppm) }\end{array}$ \\
\hline 300 & 0 & 1747 \\
\hline 300 & 3 & 1046 \\
\hline 300 & 6 & 839 \\
\hline 300 & 10 & 1250 \\
\hline
\end{tabular}

Source: authors' own elaboration.

Table 8 show the decrease in the time-averaged concentrations of chemical oxygen demand for a contact mass of $300 \mathrm{~g}$ of Lemna Minor. The average concentration in the initial time was $1747 \mathrm{ppm}$; when in contact with Lemna Minor for a period of 3 days the average concentration of the chemical oxygen demand decreases to 1046 ppm; for 6 days of contact the COD concentration was 839 ppm, and for 10 days an increase in the COD concentration to $1250 \mathrm{ppm}$ is obtained.

Table 9. Distribution of average COD concentrations vs. treatment time and mass of Lemna Minor.

\begin{tabular}{|c|c|c|c|c|}
\hline MASA (gramos) & TIEMPO (días) & DQO average (ppm) & Desviación estándar & N \\
\hline & 0 días & 1747,14 & 85,968 & 7 \\
\hline \multirow{2}{*}{100 gramos } & 3 dias & 1061,71 & 59,905 & 7 \\
\hline & 6 dias & 748,57 & 86,877 & 7 \\
\hline
\end{tabular}




\begin{tabular}{|c|c|c|c|c|}
\hline MASA (gramos) & TIEMPO (días) & DQO average (ppm) & Desviación estándar & $\mathbf{N}$ \\
\hline \multirow{5}{*}{200 gramos } & 0 días & 1747,14 & 85,968 & 7 \\
\hline & 3 dias & 912,86 & 59,362 & 7 \\
\hline & 6 dias & 602,86 & 51,223 & 7 \\
\hline & 10 dias & 684,29 & 61,606 & 7 \\
\hline & Total & 986,79 & 465,936 & 28 \\
\hline \multirow{5}{*}{300 gramos } & 0 días & 1747,14 & 85,968 & 7 \\
\hline & 3 dias & 1045,71 & 58,838 & 7 \\
\hline & 6 dias & 838,57 & 49,473 & 7 \\
\hline & 10 dias & 1250 & 96,609 & 7 \\
\hline & Total & 1220,36 & 350,571 & 28 \\
\hline \multirow{5}{*}{ Total } & 0 días & 1747,14 & 81,556 & 21 \\
\hline & 3 dias & 1006,76 & 88,581 & 21 \\
\hline & 6 dias & 730 & 117,004 & 21 \\
\hline & 10 dias & 829,52 & 318,535 & 21 \\
\hline & Total & 1078,36 & 438,263 & 84 \\
\hline
\end{tabular}

Source: authors' own elaboration.

In Table 9 the distribution of average COD concentrations vs. treatment time at different masses of Lemna Minor is shown. The results obtained according to ANOVA were determined that the best reduction of COD concentration was with a mass of $100 \mathrm{~g}$ of Lemna Minor and 10 days of treatment; the chemical oxygen demand was reduced from $1747 \mathrm{ppm}$ to $554 \mathrm{ppm}$. 


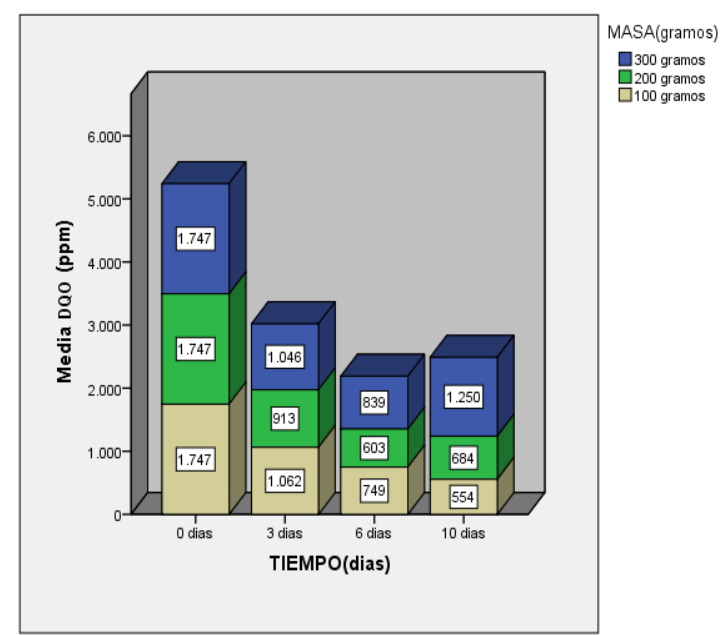

Figure 2. Average COD concentration levels vs. treatment time and mass of Lemna Minor. Source: authors' own elaboration.

Figure 2 shows the most significant reduction in average COD concentration for a treatment time of 10 days and a mass of $100 \mathrm{~g}$ from 1747 to $554 \mathrm{ppm}$. With a treatment of $200 \mathrm{~g}$ of Lemna Minor, the COD concentration decreases in 6 days from 1747 to $603 \mathrm{ppm}$ and then increases in 10 days to $684 \mathrm{ppm}$. The same behavior is obtained for treatment with $300 \mathrm{~g}$ of Lemna Minor, the COD concentration decreases in 6 days from 1747 to $639 \mathrm{ppm}$, concluding that a better treatment of organic contamination expressed as COD is obtained with a mass of $100 \mathrm{~g}$ of Lemna Minor.

Table 10. Distribution of TSS concentration averages vs. treatment time for a mass of $100 \mathrm{~g}$ of Lemna Minor.

\begin{tabular}{|c|c|c|}
\hline $\begin{array}{c}\text { Mass Lemna } \\
\text { Minor (g) }\end{array}$ & Time (days) & Media SST (ppm) \\
\hline 100 & 0 & 124 \\
\hline 100 & 3 & 82 \\
\hline 100 & 6 & 60 \\
\hline 100 & 10 & 48 \\
\hline
\end{tabular}

Source: authors' own elaboration. 
In Table 10, the decrease of the average concentrations as a function of time of the total suspended solids for a treatment with a mass of $100 \mathrm{~g}$ of Lemna Minor, the average concentration of TSS initially was $124 \mathrm{ppm}$; when being in contact for 3 days, the average concentration of TSS decreases to $82 \mathrm{ppm}$; for 6 days of contact, the concentration of TSS $60 \mathrm{ppm}$ and in 10 days a concentration of TSS at 48 ppm is obtained, obtaining a considerable reduction.

Table 11. Distribution of TSS concentration averages vs. treatment time for $200 \mathrm{~g}$ mass of Lemna Minor.

\begin{tabular}{|c|c|c|}
\hline $\begin{array}{c}\text { Mass Lemna } \\
\text { Minor (g) }\end{array}$ & Time (days) & Media SST (ppm) \\
\hline 200 & 0 & 124 \\
\hline 200 & 3 & 86 \\
\hline 200 & 6 & 63 \\
\hline 200 & 10 & 78 \\
\hline
\end{tabular}

Source: authors' own elaboration.

Table 11 show the decrease in the time-averaged concentrations of total suspended solids for treatment with $200 \mathrm{~g}$ Lemna Minor. The average concentration of TSS initially was $124 \mathrm{ppm}$; when in contact for 3 days, the average concentration of TSS decreases to $86 \mathrm{ppm}$. On the other hand, for 6 days of contact, the concentration of TSS is 63 ppm, and in 10 days, a concentration of TSS at 78 ppm is obtained, obtaining a considerable reduction.

Table 12. Distribution of TSS concentration averages vs. treatment time for $300 \mathrm{~g}$ mass of Lemna Minor.

\begin{tabular}{|c|c|c|}
\hline $\begin{array}{c}\text { Mass Lemna } \\
\text { Minor } \mathbf{( g )}\end{array}$ & Time (days) & $\begin{array}{c}\text { Media SST } \\
\text { (ppm) }\end{array}$ \\
\hline 300 & 0 & 124 \\
\hline 300 & 3 & 75 \\
\hline 300 & 6 & 51 \\
\hline 300 & 10 & 99 \\
\hline
\end{tabular}

Source: authors' own elaboration. 
In Table 12 the decrease of the average concentrations as a function of time of the total suspended solids for a treatment with a mass of $300 \mathrm{~g}$ of Lemna Minor, the average concentration of TSS initially was 124 ppm; when being in contact for 3 days the average concentration of TSS decreases to 75 ppm; for 6 days of contact the concentration of TSS to $51 \mathrm{ppm}$ and in 10 days a concentration of TSS to $99 \mathrm{ppm}$ is obtained, obtaining an increase.

Table 13. Distribution of TSS concentration averages vs. treatment time and mass of Lemna Minor.

\begin{tabular}{|c|c|c|c|c|}
\hline MASA (gramos) & TIEMPO (días) & Media SST (ppm) & Desviación estándar & $\mathbf{N}$ \\
\hline \multirow{5}{*}{100 gramos } & 0 días & 123,71 & 8,361 & 7 \\
\hline & 3 dias & 82,29 & 6,157 & 7 \\
\hline & 6 dias & 60 & 6,733 & 7 \\
\hline & 10 dias & 48,43 & 4,685 & 7 \\
\hline & Total & 78,61 & 29,93 & 28 \\
\hline \multirow{5}{*}{200 gramos } & 0 días & 123,71 & 8,361 & 7 \\
\hline & 3 dias & 85,86 & 6,283 & 7 \\
\hline & 6 dias & 63 & 3,367 & 7 \\
\hline & 10 dias & 77,71 & 4,923 & 7 \\
\hline & Total & 87,57 & 23,524 & 28 \\
\hline \multirow{5}{*}{300 gramos } & 0 días & 123,71 & 8,361 & 7 \\
\hline & 3 dias & 74,71 & 7,544 & 7 \\
\hline & 6 dias & 51,14 & 3,288 & 7 \\
\hline & 10 dias & 98,57 & 2,507 & 7 \\
\hline & Total & 87,04 & 28,083 & 28 \\
\hline \multirow{5}{*}{ Total } & 0 días & 123,71 & 7,932 & 21 \\
\hline & 3 dias & 80,95 & 7,934 & 21 \\
\hline & 6 dias & 58,05 & 6,845 & 21 \\
\hline & 10 dias & 74,9 & 21,445 & 21 \\
\hline & Total & 84,4 & 27,295 & 84 \\
\hline
\end{tabular}

Source: authors' own elaboration. 


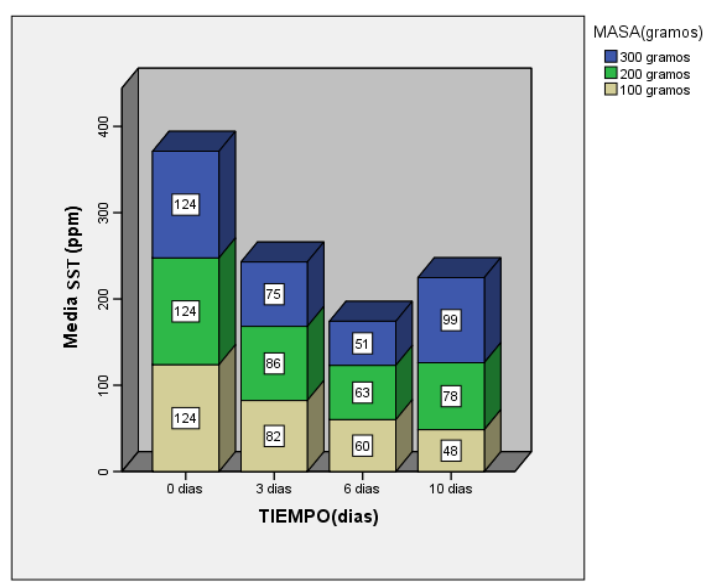

Figure 3. Average TSS concentration levels vs. treatment time and Lemna Minor mass. Source: authors' own elaboration.

In Figure 3, it can be seen that the most significant reduction in average TSS concentration is achieved with a treatment time of 10 days and a mass of $100 \mathrm{~g}$ of 124 to $48 \mathrm{ppm}$. With a treatment of Lemna Minor of $200 \mathrm{~g}$, the concentration of TSS decreases in 6 days from 124 to $63 \mathrm{ppm}$. It then increases in 10 days to $78 \mathrm{ppm}$; the same behavior is obtained for treatment with $300 \mathrm{~g}$ of Lemna Minor, the concentration of TSS decreases in 6 days from 124 to $51 \mathrm{ppm}$ and at 10 days increases to $99 \mathrm{ppm}$, concluding that a better treatment of organic contamination expressed as TSS is obtained with a mass of $100 \mathrm{~g}$ of Lemna Minor.

Table 14. Distribution of $\%$ Average removal of BOD concentration vs. treatment time for a mass of $100 \mathrm{~g}$ of Lemna Minor.

\begin{tabular}{|c|c|c|}
\hline $\begin{array}{c}\text { Masa Lemna } \\
\text { Minor }(\mathbf{g})\end{array}$ & Media DBO & \% Remotion \\
\hline 100 & $0-3$ días & 37 \\
\hline 100 & $0-6$ días & 53 \\
\hline 100 & $0-10$ días & 61 \\
\hline
\end{tabular}

Source: authors' own elaboration. 


\section{\% Average removal DBO (100 g)}

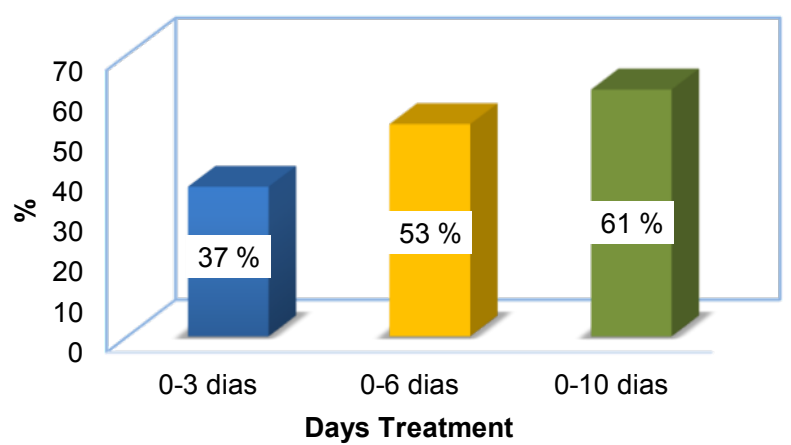

Figure 4. Average \% BOD removal concentration vs. treatment time for $100 \mathrm{~g}$ mass of Lemna Minor. Source: authors' own elaboration.

Table 14 and Figure 4 show the average levels of \% removal of BOD BOD concentration vs. treatment time for a treatment mass of $100 \mathrm{~g}$ of Lemna Minor. On the third day of treatment, $37 \%$, on the sixth day, $53 \%$, and the tenth day of treatment, $61 \%$ of average BOD removal was obtained. It is concluded that for the treatment with a mass of $100 \mathrm{~g}$ of Lemna Minor, the maximum removal of BOD is obtained at the tenth day of treatment.

Table 15. Distribution of $\%$ Average removal of BOD concentration vs. treatment time for a mass of $200 \mathrm{~g}$ of Lemna Minor.

\begin{tabular}{|c|c|c|}
\hline $\begin{array}{c}\text { Mass Lemna } \\
\text { Minor }(\mathbf{g})\end{array}$ & Media DBO & \% Remotion \\
\hline 200 & $0-3$ días & 43 \\
\hline 200 & $0-6$ días & 58 \\
\hline 200 & $0-10$ días & 53 \\
\hline
\end{tabular}

Source: authors' own elaboration.

Table 15 show the average levels of \% removal of BOD concentration vs. treatment time for a treatment mass of $200 \mathrm{~g}$ of Lemna Minor. On the third day of treatment, $43 \%$, on the sixth day of $58 \%$, and the tenth day of treatment, $53 \%$ of average BOD removal was obtained. It is concluded that for the 
treatment with a mass of $200 \mathrm{~g}$ of Lemna Minor, the maximum removal of BOD is obtained on the sixth day of treatment.

Table 16. Distribution of average removal of BOD concentration vs. treatment time for a $300 \mathrm{~g}$ mass of Lemna Minor.

\begin{tabular}{|c|c|c|}
\hline $\begin{array}{c}\text { Mass Lemna Minor } \\
(\mathbf{g})\end{array}$ & Media DBO & \% Remotion \\
\hline 300 & $0-3$ días & 48 \\
\hline 300 & $0-6$ días & 60 \\
\hline 300 & $0-10$ días & 35 \\
\hline
\end{tabular}

Source: authors' own elaboration.

\section{$\%$ media remotion DBO (300 g)}

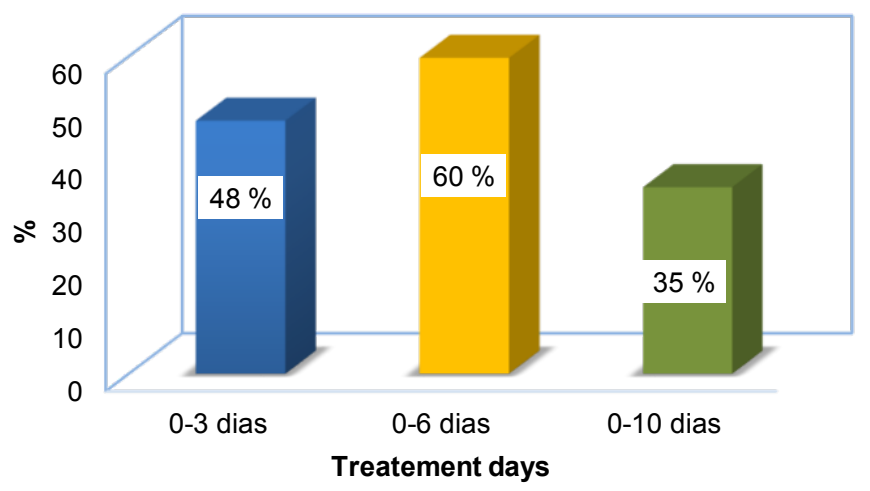

Figure 5. Average \% removal of BOD concentration vs. treatment time for $300 \mathrm{~g}$ mass of Lemna Minor. Source: authors' own elaboration.

In Table 16 and Figure 5, the average levels of \% removal of concentration of the biochemical demand of oxygen BOD versus the time of treatment for a treatment mass of $300 \mathrm{~g}$ of Lemna Minor is observed, obtaining $48 \%$ on the third day of treatment, $60 \%$ on the sixth day and $35 \%$ on the tenth day of treatment of average removal of BOD. It is concluded that for the treatment with a mass of $300 \mathrm{~g}$ of Lemna Minor, the maximum removal of BOD is obtained on the sixth day of treatment. 


\section{DISCUSSION}

Sarango, Sánchez and Landívar (2016), in their experimental design and applied type, designed 2 biofilters of $68 \mathrm{~L}$ capacity each. In contrast to the present research, both investigations were carried out with Lemna Minor applied to industrial effluents, in which there is a percentage of removal expressed as COD $72.57 \%$, BOD5 $73.36 \%$, total solids $75.21 \%$ and in the first six days of treatment with different masses of $100 \mathrm{~g}, 200 \mathrm{~g}$ of Lemna Minor there is a high percentage of decrease in the concentrations of the parameters mentioned expressed as organic matter. In the treatment with $300 \mathrm{~g}$ of Lemna Minor, there is a decrease but not in the same proportion. From the sixth day of treatment, there is a minimum reduction or increase depending on the masses of Lemna Minor due to a stage of withering, which decreases its capacity of assimilation.

But in both, it is concluded that there is a decrease of COD, BOD5, and TSS in the treatment of industrial effluents with Lemna Minor.

\section{CONCLUSION}

Of the three treatments of $100 \mathrm{~g}, 200 \mathrm{~g}$, and $300 \mathrm{~g}$ of Lemna Minor, it is observed that the parameter of BOD obtains a greater removal at 10 days of treatment with a mass of $100 \mathrm{~g}$ Lemna Minor and 6 days with $300 \mathrm{~g}$ of Lemna Minor.

For the DQO in the treatments with $100 \mathrm{~g}, 200 \mathrm{~g}$, and $300 \mathrm{~g}$ of Lemna Minor, a greater removal is obtained to the 10 days of treatment with a mass of $100 \mathrm{~g}$ of Lemna Minor and the 6 days with $200 \mathrm{~g}$ of Lemna Minor.

For TSS in the treatments of $100 \mathrm{~g}, 200 \mathrm{~g}$, and $300 \mathrm{~g}$ of Lemna Minor, there is a greater removal at 10 days of treatment with a mass of $100 \mathrm{~g}$ of Lemna Minor and at 6 days with $300 \mathrm{~g}$ of Lemna Minor. 
From the analysis of the parameters that measure organic contamination such as BOD, COD, and TSS versus contact time we found that there is an inverse relationship, as contact time increases these parameters decrease, but in the tests carried out with 200 and $300 \mathrm{~g}$ it increases from the 6th day, this occurs due to the increase of Lemna Minor that dies during the treatment.

\section{REFERENCES}

Coronel, E. (2016). Eficiencia del Jacinto de agua (Eichhornia Crassipes) y Lenteja de agua (Lemna Minor) en el tratamiento de las aguas residuales de la Universidad Nacional Toribio. Facultad de Ingeniería Civil y ambiental. Universidad Nacional “Toribio Rodríguez de Mendoza de Amazonas”. http:// repositorio.untrm.edu.pe/bitstream/handle/UNTRM/657/EFICIENCIA\%20DEL\%20 JACINTO $\% 20$ DE $\% 20$ AGUA.pdf? sequence $=1$ \&isAllowed $=\mathrm{y}$

Dirección General de Salud Ambiental e Inocuidad Alimentaria (DIGESA). (s.f.). Ministerio de Salud. Perú. http://www.digesa.minsa.gob.pe/

\section{Esenarro, D., Rodriguez, G., Aquije, G., Obregon, N., Anicama, L., \& Arguedas, G.} (2020). Cable Car with Water Collection for Afforestation of the Solar Hill in Chorrillos, Perú. Test Engineering $\mathcal{E}$ Management, 83, 9236 - 9242. http://www.testmagzine.biz/index. $\mathrm{php} /$ testmagzine/article/view/5279

Hoyos, A., Ramirez, A., Fernandez, V., \& Sanchez, N. E. (2016). Lenteja de agua (Lemna minor) para el tratamiento de las aguas residuales que provienen del lavado de la fibra de fique (Furcraea bedinghausii). Ingenieria y Competividad, 18(2), 25-34. https://doi.org/10.25100/iyc.v18i2.2151

Jojoa, G., Rodríguez, H., \& Gardona, S. (2015). Tratamiento de aguas residuales textiles a partir de métodos biológicos. Revista CINTEX, 20(1), 11-34. https://www.academia.edu/38191080/ Tratamiento_de_aguas_residuales_textiles_a_partir_de_m\%C3\%A9todos_biol\% C $3 \%$ B3gicos 
Li, H., Mo, F., Li, Y., Wang, M., Li, Z., Hu, H., Deng, W., \& Zhang, R. (2020). Effects of silver (I) toxicity on microstructure, biochemical activities, and genic material of Lemna minor L. with special reference to application of bioindicator. Environmental Science \& Pollution Research, 27(18), 22735-22748. https://doi.org/10.1007/s11356-020-08844-8

Rodriguez, C., Esenarro, D., Gcorimanya, P., Flores, F., Aylas, C., \& Lagos, J. (2020). Proposal for a sustainable infrastructure design (ecolodge) in the Quichas Town, Perú. Test Engineering and Management, 83, 9250-9256. http://www.testmagzine.biz/index.php/testmagzine/ article/view/5281

Sarango, J. A., Sánchez, S., \& Landívar, J. (2016). Educación ambiental. ¿Por qué la Historia?. Revista Universidad y Sociedad, 8(3), 184-187. http://scielo.sld.cu/scielo.php?script=sci_ abstract\&pid=S2218-36202016000300025\&lng=es\&nrm=iso

Sun, Y., Gao, P., Ding, N., Zou, X., Ghen, Y., Li, T., Guiting, W., Xu, X., Ghen, T., Ruan, H. (2020). Feasible Green Strategy for the Quantitative Bioaccumulation of Heavy Metals by Lemna minor: Application of the Self-Thinning Law. Bulletin of Environmental Contamination EF Toxicology, 104(2), 282-287. https://doi.org/10.1007/s00128-019-02772-1

Walsh, É., Paolacci, S., Burnell, G., Jansen, M. A. K. (2020). The importance of the calcium-tomagnesium ratio for phytoremediation of dairy industry wastewater using the aquatic plant Lemna minor L. International Fournal of Phytoremediation, 22(7), 694-702. https://doi.org/10.1080/152265 14.2019 .1707478 
